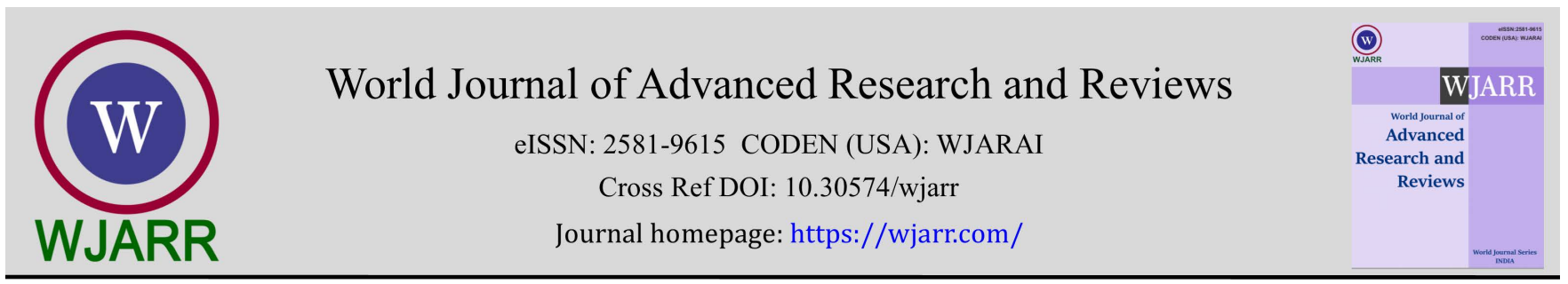

(RESEARCH ARTicle)

Check for updates

\title{
Assessment of the proximate composition, sensory acceptability and microbial loads of unripe plantain flour fortified with dry herring fish
}

\author{
Olajumoke Adeogun 1, ${ }^{*}$, Oluwatoyin Adegoriola Tiamiyu ${ }^{1}$, Adebola Atinuke Alabi ${ }^{1}$ and Idayat Oluwayemisi \\ Akindele 2 \\ ${ }^{1}$ Department of Hospitality, Leisure and Tourism Management, Moshood Abiola Polytechnic, Abeokuta, Ogun State, \\ Nigeria. \\ 2 Department of Science Laboratory Technology, Moshood Abiola Polytechnic, Abeokuta, Ogun State, Nigeria.
}

World Journal of Advanced Research and Reviews, 2021, 10(03), 104-112

Publication history: Received on 28 April 2021; revised on 06 June 2021; accepted on 10 June 2021

Article DOI: https://doi.org/10.30574/wjarr.2021.10.3.0257

\begin{abstract}
Health challenges are on the increase daily due to insufficient nutrient in the body therefore there is a need to solve the problems. Therefore, this study determined the proximate composition, sensory and microbial qualities of unripe plantain flour fortified with dry Herring fish ('Shawa'). Unripe plantain flour was mixed with herring fish flour at different levels (100:0, 95:5, 90:10, 85:15 and 80:20). Proximate composition and microbial loads of the fortified flours were determined using standard laboratory procedures. Sensory acceptability of 'Amala' prepared with the fortified plantain flours was determined using 7-point hedonic scale of preference. Data obtained were subjected to statistical analysis using SPSS (version 21.00). The samples were significantly $(\mathrm{p} \leq 0.05)$ different from one another in terms of all the qualities evaluated. The result of the proximate analysis revealed that the percentage of protein, crude fibre, ash and fat content of unripe plantain flour increased while carbohydrate decreased as level of addition of herring fish flour to plantain flour increased. Sample containing 20\% herring fish flour had the highest while $100 \%$ unripe plantain flour had the lowest. The microbial loads were within the acceptable level recommended for flour samples. Absence of coliform in almost all the flours evaluated revealed the level of hygienic condition at which the samples were prepared. The sensory acceptability result showed that the unripe plantain flour fortified with $10 \%$ fish flour was the most acceptable. Fortification at $20 \%$ level had the highest protein content, therefore can be recommended for infant, growing children and adults.
\end{abstract}

Keywords: Fortified flour; Protein; 'Amala'; Fish flour; Plantain flour

\section{Introduction}

Plantain (Musa paradisiacal, family Musaceae) is a plant genus of extraordinary significance to human societies, produces the fourth most important food in the world today (after rice, wheat, and maize). Plantain is a central fruit crop of the tropical and subtropical regions of the world grown on about 8.8 million hectares [1]. It is an important staple food in central and West Africa, which along with bananas provide 60 million people with $25 \%$ or their calories [2]. They have been a staple of the human diet since the dawn of recorded human history. Musa species attained a position of central importance within Pacific societies and the plant is a source of food, beverages, fermentable sugars, medicines, flavorings, animal feed, shelter, numerous ceremonials, and religious uses. Unripe plantain meal is usually consumed by Nigerian diabetic patients to reduce the blood glucose level. As a diet, plantain is an affluent source of carbohydrate with calorific value of 67 calories per $100 \mathrm{~g}$ fruit and is one of the most well-liked and widely traded fruits across the world [3-5]. It is highly nutritious and is more easily digested [6].

\footnotetext{
${ }^{*}$ Corresponding author: Olajumoke Adeogun

Department of Hospitality, Leisure and Tourism Management, Moshood Abiola Polytechnic, Abeokuta, Ogun State, Nigeria. 
Due to rampant heath issues there is need for the development of nutritionally rich food which will be required to prevent protein energy malnutrition (PEM) in every individual from childhood to aged. A Worldwide prevalence of diabetics is predicted to increase from 382 million people to 592 million by the end of 2035 , and approximately $10 \%$ of the population will have diabetics [7].

Plantain flour is reported to have potent anti-ulcer activity which is attributed to the active ingredient flavonoid leucocyanidin. Furthermore, consumption of plantain flour has also shown anti-atherosclerotic activity in rats and has been noted to reduce systolic blood pressure in humans. The incorporation of plantain Flour into foods has been encouraged due to its relatively high resistant starch content which has been recommended for dietary management of diabetics' mellitus and other related disease 18]. Mature plantain pulp is very rich in iron, potassium, vitamin A and ascorbic acid but low in protein [9].

Fish is considered to be a protein dense commodity; it contains digestible protein due to lack of strong collagenous fibre and tendon which increases its consumption by humans [10]. The most important species for the fishery in the Baltic Sea and Gulf of Bothnia is herring (Clupea harengus membras), which is a subspecies of the larger North Atlantic herring (Clupea harengus). Herring is probably one of the most studied fish species in the World [11]. Herring has a large impact on ecosystem function, similar to a key species; in the sense that it represents a large biomass of pelagic marine life and thus can have a major impact on the marine ecosystem [12].

Herring ('Shawa') is very important in West African coastal and lagoon fishing communities and it is an important food source in West and Central Africa [13]. They are forage fish mostly belonging to the family Clupeidae. They are probably one of the most studied fish in the World. It is usually smoke-dried for 2 to 5 days, depending on size and the market demand. Smoke-drying is done over charcoal. Dry fish is a very favorite food item in Nigeria and has a good market demand besides fresh fish and sea food products. It is a low-cost dietary protein source and used as a substitute of fresh fish. Fish products contain most important nutritional components and serve as a source of protein and energy for human beings [14].

Food fortification or enrichment is the process of adding micronutrients (essential elements and vitamins) to food or the practice of deliberately increasing the content of an essential micronutrient in food, irrespective of whether the nutrients were originally in the food before processing or not so as to improve the nutritional quality of the food supplied and provide a public health benefit with minimum risk to health.

Nutritionally, fish proteins have high digestible essential amino acids and the most important function of fish in all major fish-eating countries is to provide high quality protein. The fat of fish is readily digestible and rich in unsaturated fatty acids, nutritionists often emphasize the importance of fish in diets. Like all unsaturated fatty acids, those in fish are highly susceptible to oxidation and the development of off-flavours and rancidity. Fish are rich in vitamins; the fat in fish is an excellent source of vitamins A and D. Therefore, the aim of this study was to determine the proximate composition, sensory and microbiological qualities of unripe plantain flour fortified with dry Herring fish ('Shawa') powder.

\section{Material and methods}

\subsection{Source of materials}

Dry Herring fish (Shawa) and mature unripe plantains were purchased from Lafenwa market in Abeokuta, Ogun state, Nigeria.

\subsection{Methods}

\subsubsection{Production of unripe plantain flour}

The production of unripe plantain flour was produced according to the method described by [15]. The matured unripe plantain fruits were sorted and graded, washed, peeled and sliced to about $5 \mathrm{~mm}$ diameter using a slicer. The slices were steamed for $15 \mathrm{~min}$ to activate the enzymes. The sliced plantain was drained and dried in a cabinet drier at $60{ }^{\circ} \mathrm{C}$ for $24 \mathrm{hrs}$, after which the dried plantain slices were milled into flour. The flour was then sieved through a $0.25 \mathrm{~mm}$ sieve and packed in airtight container to keep it fresh prior to analyses to prevent absorption of moisture.

\subsubsection{Preparation of Dry Herring Fish ('Shawa')}

Dry Herring fish ('Shawa') were sorted, graded, scales removed, deboned and then milled into powder. 


\subsubsection{Fortification}

The unripe plantain flour was fortified with the dry fish powder at $0 \%, 5 \%, 10 \%, 15 \%$ and $20 \%$ levels weight. The mixtures were thoroughly mixed and kept in airtight plastic containers for laboratory analysis. Sample A had the composition of $100 \%$ plantain flour which serves as the control, Sample B had the dry fish fortification of 5\% and $95 \%$ plantain flour, sample C has $10 \%$ of dry fish and $90 \%$ of plantain flour, sample D is composed of $15 \%$ dry fish and $85 \%$ plantain flour while sample $\mathrm{E}$ had $20 \%$ dry fish and $80 \%$ plantain flour respectively.

\subsubsection{Preparation of Paste ('Amala')}

The plantain flour meal was prepared by stirring continuously $225 \mathrm{~g}$ flour at different levels of fortification $(0 \%, 5 \%$, $10 \%, 15 \%$ and $20 \%$ ) in a pot of $250 \mathrm{ml}$ boiling water each until well cooked to form a thick, smooth brown paste known as 'Amala'.

\subsection{Analysis of Samples}

\subsubsection{Determination of Proximate Composition}

Proximate analysis of the unripe plantain flour fortified with dry herring fish ('shawa') including moisture, ash, crude protein, fat, dry matter and crude fibre was determined using [16]. Carbohydrate was determined by difference.

\subsubsection{Microbial Analysis of flour}

Total (Aerobic) Plate Count

One gram of the sample was added to $10 \mathrm{ml}$ of sterile distilled water to make $10 \%$ of the stock solution. 10 -fold dilution of each sample was made in sterile distilled water from $10^{-1}$ to $10^{-6} .1 \mathrm{ml}$ of the diluted sample was aseptically added to sterile petri dish and $20 \mathrm{ml}$ of molten agar (cooled to $46^{\circ} \mathrm{C}$ ) was poured onto it. This was done in triplicate. The plate was incubated at $37^{\circ} \mathrm{C}$ for 24 hours. Plate count was done manually by counting the number of colonies and the result multiplied by the dilution factor.

\section{Escherichia coli Count}

One gram of the sample was added to $10 \mathrm{ml}$ of sterile distilled water to make $10 \%$ of the stock solution. 10 -fold dilution of this sample was made in sterile distilled water from $10^{-1}$ to $10^{-6} .1 \mathrm{ml}$ of the diluted sample was aseptically added to sterile petri dish and $20 \mathrm{ml}$ of Eosin Methylene blue (EMB) agar (cooled to $46^{\circ} \mathrm{C}$ ) was poured onto it. This was done in triplicate. The plate was incubated at $37^{\circ} \mathrm{C}$ for 24 hours. Plate count was done manually by counting the number of colonies and the result multiplied by the dilution factor.

\section{Staphylococcal Count}

One gram of the sample was added to $10 \mathrm{ml}$ of sterile distilled water to make $10 \%$ of the stock solution. 10 -fold dilution of this sample was made in sterile distilled water from $10^{-1}$ to $10^{-6} .1 \mathrm{ml}$ of the diluted sample was aseptically added to sterile petri dish and $20 \mathrm{ml}$ of Mannitol Salt agar (MSA) (cooled to $46^{\circ} \mathrm{C}$ ) was poured onto it. This was done in triplicate. The plate was incubated at $37^{\circ} \mathrm{C}$ for 24 hours. Plate count was done manually by counting the number of colonies and the result multiplied by the dilution factor.

\section{Salmonella and Shigella Count}

One gram of the sample was added to $10 \mathrm{mls}$ of sterile distilled water to make $10 \%$ of the stock solution. 10 -fold dilution of this sample was made in sterile distilled water from $10^{-1}$ to $10^{-6} .1 \mathrm{ml}$ of the diluted sample was aseptically added to sterile petri dish and $20 \mathrm{ml}$ of Salmonella and Shigella (SS) agar (cooled to $46^{\circ} \mathrm{C}$ ) was poured onto it. This was done in triplicate. The plate was incubated at $37^{\circ} \mathrm{C}$ for 24 hours. Plate count was done manually by counting the number of colonies and the result multiplied by the dilution factor.

\section{Identification/Characterization of Bacterial Isolates}

Bacterial isolates were identified morphologically viz: size, shape, colour, consistency, edges, elevation, and opacity. They were further identified by staining (Gram, Spore and Capsule staining) and biochemically characterized viz: indole, motility, catalase, urease, citrate, methyl-red, voges proskeur, hydrogen sulphide and sugar fermentation test. 


\subsubsection{Sensory Evaluation}

A total of 25 semi trained panelists being students and staff of Hospitality Management Department of Moshood Abiola Polytechnic, Abeokuta assessed the sensory quality of paste ('Amala'). A 7- point hedonic scale where 1 represent dislike extremely and 7 represented like extremely was used to score samples based on consumer's preference for colour, taste, aroma, texture and overall acceptability [17].

\subsection{Statistical analysis}

The data obtained from proximate and sensory evaluation were subjected to one-way analysis of variance (ANOVA). Duncan Multiple Range Test (DMRT) was used to determine the significant difference. All tests were conducted at 5\% significance level and carried out using SPSS (Version 21.0).

\section{Results and discussion}

\subsection{Proximate composition of Unripe Plantain flour fortified with Dry Fish ('Shawa') powder}

The data obtained on the proximate composition of plantain flour fortified with dry herring fish ('Shawa') powder are presented in table 1 . The result of the moisture, fat, protein, crude fibre, ash and carbohydrate content ranged from $13.15-13.71 \%, \quad 1.59-2.68 \%, 9.40-12.68 \%, 2.45-4.43 \%, 3.10-3.87 \%$ and $62.63-70.31 \%$ respectively. There was significant $(\mathrm{p} \leq 0.05)$ difference among the samples of flours investigated. The result showed that the proximate composition except the carbohydrate obtained increases gradually as the level of fortification of unripe plantain flour with dry fish powder increases. Moisture content of any food material is the indicator of the life span of the food i.e. it indicates how long the food will be stored without becoming mouldy, The moisture content of food influences its texture and high moisture makes bacteria to dissolve and digest food. This implies that the lower moisture contents in the samples can slow down the multiplication or the growth of microorganisms thereby increasing the shelf life. Fats are very chemically stable and so they are not likely to react with other cell constituents making them a safe form of storing energy. The insulating layer of fat just beneath the skin is made mostly of triglycerides. Fat tissues also surround and protect some organs-kidney, for example, from injury. Fat is essential components of tissues and a veritable for fat soluble vitamins A, D, E and K. It is able to supply thrice the amount of required by the body [18]. About half of the energy used by the entire body at rest and during light activities comes from fat. The body stores energy mainly in the form of fat. An important advantage of using fat to store energy in the body is that they are energy dense. The fat content of the fortified plantain flour was observed to be higher than that of the unfortified plantain flour which shows that the herring fish powder contain some considerable amount of fat and could be of advantage. Significant increase $(p<0.05)$ was observed in terms protein content (i.e. the plantain flour fortified with dry fish powder increased with increased level of fortification). The unfortified plantain flour has the lowest value of protein (9.40\%) while sample containing $20 \%$ dry herring fish powder had the highest protein value of $12.68 \%$. Protein is has been identified as a key nutrient for growth most especially for infant, therefore, the samples containing the herring fish powder with high amount of protein revealed a nutritionally high product. The crude fibre also increased with the substitution of plantain flour with dry fish. Sample containing $20 \%$ herring fish flour has the highest significant value (4.43\%) while unripe plantain flour which serves as the control had the lowest (2.45\%). Fibers and roughages are substances in plant food that are not digested by the process that takes place in the intestine. Fibres supply mass to the faeces, making elimination much easier and reduce constipation. When enough fibre is consumed, the stool is large size, stimulates and soft because many types of plant fibres attract water. The large size stimulates the intestinal muscles, which aids elimination of waste substances. Consequently less pressure is necessary to expel the stool may be small and hard which could result into cases of constipation, this is in turn could extent excessive pressure in the large intestine (colon) wall out from between the surrounding bands of muscle forming small ponches diverticula. A diet high in fibre likely aids weight control and reduces the risk of developing obesity and related diseases. The bulky nature of high fibre foods fill up without yielding much energy. Increasing intake of food rich in fibre is one strategy for remaining satisfied after a meal. The health benefit to the colon that stem from high fibre diet are probably due mostly to the nutrients that are commonly part of high fibre foods, such as vitamins, minerals phytochemicals, antioxidants, and in some cases essential fatty acids. Soluble fibre slow glucose absorption from the small intestine and so contribute to better blood glucose regulation. This effect can be helpful in the treatment of diabetics. A fibre rich diet is advocated as part of a strategy to reduce cardiovascular diseases. The ash content also increases with the increase level of substitution of plantain flour with fish powder. The ash content of the unripe plantain flour (control) was the lowest with the value of $3.10 \%$ while the sample containing the highest percentage of fish powder had the highest (3.87\%). The ash content is the indicative of the minerals in food. The metabolic roles of minerals and the amounts of them vary considerably. Minerals distinctly pay important roles in maintaining body function. Reverse is the case for the carbohydrate content in that the sample containing $20 \%$ herring fish flour was the lowest (62.63\%) while the unripe plantain flour had the highest value of carbohydrates $(70.31 \%)$. High energy foods tend to have a protective effect in the optimal utilization of other nutrients [18]. 
World Journal of Advanced Research and Reviews, 2021, 10(03), 104-112

Table 1 Proximate composition of unripe plantain flour fortified with dry herring fish ('Shawa') powder

\begin{tabular}{|c|c|c|c|c|c|c|}
\hline Sample & $\begin{array}{c}\text { Moisture } \\
\text { (\%) }\end{array}$ & Fat (\%) & $\begin{array}{c}\text { Protein } \\
\text { (\%) }\end{array}$ & $\begin{array}{c}\text { Crude Fibre } \\
\text { (\%) }\end{array}$ & $\begin{array}{c}\text { Ash (\%) } \\
\text { Carbohydrate } \\
\text { (\%) }\end{array}$ \\
\hline A & $13.15^{\mathrm{a}} \pm 0.16$ & $1.59^{\mathrm{a}} \pm 0.12$ & $9.40^{\mathrm{a}} \pm 0.14$ & $2.45^{\mathrm{a}} \pm 0.71$ & $3.10^{\mathrm{a} \pm 0.42}$ & $70.31^{\mathrm{e} \pm 0.86}$ \\
\hline B & $13.38^{\mathrm{b}} \pm 0.23$ & $1.75^{\mathrm{b}} \pm 0.14$ & $10.73^{\mathrm{b}} \pm 0.33$ & $2.85^{\mathrm{b} \pm 0.56}$ & $3.33^{\mathrm{a} \pm 0.58}$ & $67.96^{\mathrm{d} \pm 0.57}$ \\
\hline C & $13.52^{\mathrm{c}} \pm 0.28$ & $1.94^{\mathrm{c}} \pm 0.85$ & $11.37^{\mathrm{c}} \pm 0.71$ & $3.32^{\mathrm{c}} \pm 0.45$ & $3.52^{\mathrm{b} \pm 0.71}$ & $66.33^{\mathrm{c} \pm 0.64}$ \\
\hline D & $13.55^{\mathrm{c}} \pm 0.47$ & $2.35^{\mathrm{d}} \pm 0.17$ & $11.91^{\mathrm{d}} \pm 0.45$ & $3.83^{\mathrm{d} \pm 0.45}$ & $3.61^{\mathrm{b}} \pm 0.17$ & $64.75^{\mathrm{b} \pm 1.24}$ \\
\hline E & $13.71^{\mathrm{d}} \pm 0.14$ & $2.68^{\mathrm{e}} \pm 1.13$ & $12.68^{\mathrm{e}} \pm 0.66$ & $4.43^{\mathrm{e}} \pm 0.61$ & $3.87^{\mathrm{c}} \pm 0.45$ & $62.63^{\mathrm{a}} \pm 1.27$ \\
\hline
\end{tabular}

Values are means \pm S.D of triplicate determinations. Values in the same column with different subscript are significantly different $(\mathrm{p}<0.05)$ Keys: A- $100 \%$ unripe plantain flour; B-95\% unripe plantain flour fortified with $5 \%$ dry herring fish ('shawa') powder; C-90\% unripe plantain flour fortified with 10\% dry herring fish ('shawa') powder; D-85\% unripe plantain flour fortified with 15\% dry herring fish ('shawa') powder; E-80\% unripe plantain flour fortified with $20 \%$ dry herring fish ('shawa') powder

\subsection{Microbial loads of unripe plantain flour fortified with dry fish ('Shawa') powder}

The results obtained on the microbial loads of plantain flour fortified with dry herring fish powder are as shown in tables 2-5. In microbial analysis of food, the number and type of microbes present in the food material under examination reflect quality of the food and extent of risk poised to the consumers [19]. Total viable count according to Uzoaga and Kanu [20] has been described as a means of predicting the shelf life of a food. In this study, the level of contamination of the flours is minimal and within standard range of $\times 10^{6} \mathrm{cfu} / \mathrm{g}$. Total counts have been reported to be useful monitor in processing of food products and may therefore reflect poor handling or storage at retail level [21]. It was reported by Noah and Banjo [22] that the increase in microbial loads observed in the cookies fortified with red kidney beans was due to red kidney beans with high protein content which usually encourages microbial action on food. Olorode and Ewuoso [23] also reported that addition of sesame seed flour of high protein to yellow cassava flour increased the microbial load of product from the flours hence the result in this present study with addition of proteinous fish powder corroborate this findings/significance of protein in microbial action. Total viable count is an indication that effective and efficient method of handling samples has to be put in place as microbial load of any sample is directly related to the shelf life of the samples. International Commission on Microbiological Specification for Food ICMSF [24] stated that yeast and mould count should not exceed $1 \times 10^{5} \mathrm{cfu} / \mathrm{g}$. The microbial loads $\left(11.00 \times 10^{6}\right.$ to $\left.24.00 \times 10^{6} \mathrm{cfu} / \mathrm{g}\right)$ of the flours (table 2) in this present study were within the recommended safe limits. The loads observed for faecal indicator, E. coli.

Table 2 Total Viable Count of Bacteria isolated from flour

\begin{tabular}{|c|c|c|}
\hline $\begin{array}{c}\text { Flour } \\
\text { Sample }\end{array}$ & $\begin{array}{c}\text { Total Viable Count } \\
\left(\times 10^{6} \mathrm{cfu} / \mathrm{g}\right)\end{array}$ & Isolated Organism \\
\hline A & 11.00 & Bacillus subtilis, Staphylococcus aureus \\
\hline B & 24.00 & Bacillus subtilis, Staphylococcus aureus \\
\hline $\mathrm{C}$ & 19.00 & Bacillus subtilis, Klebsiella spp. \\
\hline $\mathrm{D}$ & 15.00 & Bacillus subtilis, Klebsiella spp. \\
\hline $\mathrm{E}$ & 21.00 & Bacillus subtilis, Klebsiella spp. \\
\hline
\end{tabular}

Keys: A-100\% unripe plantain flour: B-95\% unripe plantain flour fortified with 5\% dry herring fish ('shawa') powder: C- 90\% unripe plantain flour fortified with 10\% dry herring fish ('shawa') powder: D-85\% unripe plantain flour fortified with 15\% dry herring fish ('shawa') powder: E-80\% unripe plantain flour fortified with $20 \%$ dry herring fish ('shawa') powder

In two fortified samples as shown in table 3 revealed that stringent hygienic measures is needed for these samples. The E. coli count in this present study agrees with a research done by Berghofer et al. [25]. The result obtained for the Staphylococcus aureus is as shown in table 4. The estimation of Staphylococcus in the flour revealed the possibility of cross contamination between the handlers and the samples as the minimum mean recorded was $2.0^{\circ} \mathrm{Cfu} / \mathrm{g}$ for unripe plantain flour (control) and $6.0^{\circ} \mathrm{Cfu} / \mathrm{g}$ for sample containing $5 \%$ herring fish powder Fungi which comprises of mould and yeast isolated from the samples includes Aspergillus niger, Aspergillus fumigatus, Mucor spp. and Rhizopus spp. Higher level of fungi in food samples contributes to deterioration of quality of food and causes food borne diseases. The 
highest plate count obtained was $35.00 \times 10^{5} \mathrm{cfu} / \mathrm{g}$ which is within the recommended limit of $\log 10 \mathrm{cfu} / \mathrm{g}$ as shown in table 5.

Table 3 Total Viable Count of Escherichia coli isolated from flour

\begin{tabular}{|c|c|c|}
\hline Flour Sample & Total Viable Count $\left.\mathbf{( \times 1 0 ^ { 6 }} \mathbf{c f u} / \mathbf{g}\right)$ & Isolated Microorganism \\
\hline A & Nil & Nil \\
\hline B & Nil & E. coli \\
\hline C & 4.00 & E. coli \\
\hline D & 3.00 & Nil \\
\hline E & Nil & P \\
\hline
\end{tabular}

Keys: A-100\% unripe plantain flour ; B-95\% unripe plantain flour fortified with 5\% dry herring fish ('shawa') powder; C-90\% unripe plantain flour fortified with 10\% dry herring fish ('shawa') powder; D-85\% unripe plantain flour fortified with $15 \%$ dry herring fish ('shawa') powder; E-80\% unripe plantain flour fortified with $20 \%$ dry herring fish ('shawa') powder

Table 4 Total Viable Count of Staphylococcus aureus isolated from flour

\begin{tabular}{|c|c|c|}
\hline Flour Samples & Total Viable Count $\left.\mathbf{( \times 1 0 ^ { 6 }} \mathbf{c f u} / \mathbf{g}\right)$ & Isolated Organism \\
\hline A & 2.00 & Staph. aureus \\
\hline B & 6.00 & Staph. aureus \\
\hline C & Nil & Nil \\
\hline D & Nil & Nil \\
\hline E & Nil & Nil \\
\hline
\end{tabular}

Keys: A-100\% unripe plantain flour ; B-95\% unripe plantain flour fortified with 5\% dry herring fish ('shawa') powder; C-90\% unripe plantain flour fortified with 10\% dry herring fish ('shawa') powder; D-85\% unripe plantain flour fortified with $15 \%$ dry herring fish ('shawa') powder; E-80\% unripe plantain flour fortified with $20 \%$ dry herring fish ('shawa') powder

Table 5 Total fungal plate count and microorganisms isolated from flour

\begin{tabular}{|c|c|c|}
\hline Flour samples & Plate count ( $x \mathbf{1 0}^{5} \mathrm{cfu} / \mathrm{g}$ ) & Isolated Organism \\
\hline A & 35.0 & $\begin{array}{l}\text { Aspergillus niger, Aspergillus fumigatus, Mucor spp., } \\
\text { Rhizopus spp. }\end{array}$ \\
\hline B & 15.0 & Aspergillus niger, Aspergillus fumigatus, Mucor spp. \\
\hline $\mathrm{C}$ & 10.0 & Aspergillus niger, Aspergillus fumigatus \\
\hline $\mathrm{D}$ & 12.0 & Aspergillus niger, Aspergillus fumigatus, Rhizopus spp \\
\hline E & 15.0 & Aspergillus niger, Aspergillus fumigatus, Mucor spp \\
\hline
\end{tabular}

Keys: A-100\% unripe plantain flour ; B-95\% unripe plantain flour fortified with 5\% dry herring fish ('shawa') powder; C-90\% unripe plantain flour fortified with 10\% dry herring fish ('shawa') powder; D-85\% unripe plantain flour fortified with $15 \%$ dry herring fish ('shawa') powder; E- $80 \%$ unripe plantain flour fortified with $20 \%$ dry herring fish ('shawa') powder

\subsection{Sensory Evaluation of Paste ‘Amala' produced from Unripe Plantain flour fortified with Dry Fish ('Shawa') powder}

The result of sensory evaluation of Paste 'Amala' produced from Unripe Plantain flour fortified with Dry Herring Fish ('Shawa') powder on a 7-point hedonic scale rating where 1 represent (dislike extremely) and 7 represents (like extremely) is as shown in table 6. The results obtained in the colour of the sensory evaluation of the amala samples ranged between 3.20 and 6.70; there was significant $(\mathrm{p} \leq 0.05)$ increase in the values as the level of fortification increases. Highest value of taste was obtained in sample containing $20 \%$ fish powder with the value of 6.50 , while sample containing 15\% dry fish powder ranked next with the value of 6.00 while the 'Amala produced with $100 \%$ unripe plantain had the lowest acceptability score of taste (3.80). The case is also the same for the aroma preference score for 'Amala' Texture is an important sensory attribute that influences customer selection and acceptability of product. Texture is influenced by the physical characteristics of the flours such as particle size [26]. The preference score for 
texture decreases as the level of fish powder increases may be due to the change (reduction) in firmness of the paste (Amala') but still acceptable even at high level of addition of fish flour to the unripe plantain flour for 'Amala'. The overall acceptance expresses how the consumers or panelists accept the product generally. The higher the level of fortification of fish with plantain flour, the higher the overall acceptability as revealed by the overall acceptability score.

Table 6 Sensory Scores of 'Amala' produced from Plantain flour fortified with dry herring fish ('Shawa') powder

\begin{tabular}{|c|c|c|c|c|c|}
\hline Samples & Colour & Taste & Aroma & Texture & Overall acceptability \\
\hline A & $6.70^{\mathrm{a}}$ & $3.80^{\mathrm{d}}$ & $3.2^{\circ} \mathrm{C}$ & $6.30^{\mathrm{a}}$ & $4.8^{\circ} \mathrm{C}$ \\
\hline B & $6.20^{\mathrm{a}}$ & $4.8^{\circ} \mathrm{C}$ & $4.40^{\mathrm{b}}$ & $5.20^{\mathrm{d}}$ & $4.1^{\circ} \mathrm{C}$ \\
\hline C & $4.60^{\mathrm{b}}$ & $4.9^{\circ} \mathrm{C}$ & $4.30^{\mathrm{b}}$ & $5.0^{\circ} \mathrm{C}$ & $5.70^{\mathrm{a}}$ \\
\hline D & $4.3^{\circ} \mathrm{C}$ & $6.00^{\mathrm{b}}$ & $6.20^{\mathrm{a}}$ & $4.10^{\mathrm{b}}$ & $4.8^{\circ} \mathrm{C}$ \\
\hline E & $3.20^{\mathrm{d}}$ & $6.50^{\mathrm{a}}$ & $6.90^{\mathrm{a}}$ & $4.40^{\mathrm{a}}$ & $5.60^{\mathrm{b}}$ \\
\hline
\end{tabular}

Values are means of multiple determinations. Values in the same column with different subscript are significantly different (p<0.05) Keys: A-100\% unripe plantain flour; B-95\% unripe plantain flour fortified with 5\% dry herring fish ('shawa') powder; C-90\% unripe plantain flour fortified with $10 \%$ dry herring fish ('shawa') powder; D-85\% unripe plantain flour fortified with 15\% dry herring fish ('shawa') powder; E-80\% unripe plantain flour fortified with $20 \%$ dry herring fish ('shawa') powder

\section{Conclusion}

It was observed that the protein contents of the plantain flour increased as the level of substitution with dry herring fish increased, also fat, moisture ash and fibre increases at the increased level of fortification. The samples were all accepted because non falls below 4.0 the least acceptable score on a 7 -point scale of preference but sample with $10 \%$ dry fish powder was the most preferred by the panelists.

The Substitution of plantain flour with dry fish at $20 \%$ level had the highest protein content, therefore it can be recommended for infant, children and growing adults. The fortification of plantain flour with dry herring fish formulated a diet which could militate against protein energy malnutrition, combat obesity, diabetics, malnutrition in all age groups; including infants and it will serve as a convenience meal to prepare for working groups who could not go through the rigor of the processing but need to have a healthy diet. The fortified samples should be readily available in the market with tolerable limit of preservative to increase its shelf life so as to serve the busy working groups who cannot go through the processing. Government should make the domestication of herring fish available in Nigeria as this species breeds massively and are relatively cheap compared to salmon, sardine and coho thereby making the production of fortified product affordable for all and sundry.

\section{Compliance with ethical standards}

\section{Acknowledgments}

The effort of Mrs. Omobolanle Olorode on the statistical analyses of data generated from this research is highly appreciated

\section{Disclosure of conflict of interest}

Authors declare no conflict of interest.

\section{References}

[1] Mohapatra PP, Sushii KD, Siba PP. Banana and its Bye Products Utilization; An Overview. J Sci. Ind. Res. 2010; 69: 324

[2] Adetuyi F, Ajala L, Ibrahim T. Effect of the Addition of Defatted Okra Seed (Abelmoschus esculentus) Flour on the Chemical Composition, Functional Properties and Zn Bioavailability of Plantain (Musa paradisiaca llinn) flour. J. Microbiol. Biotechnol. Food Sci. 2012; 2: 69-82.

[3] Emega TH, Andrianaivo RH, Wathelet B, Tchago JT, Paquot M. Effect of the stages of maturation and chemical composition of banana and plantain peels. Food Chemistry. 2008; 103: 590-600. 
[4] Kumar KPS, Bhowmik D, Duraivel S, Umadevi M. Traditional and Medical uses of banana Journal of Pharmacognosy and Phytochemistry. 2012; 1: 51-63.

[5] Falade KO, Olubiyi AO. Effect of maturity and drying method on the physic chemical and recomposition properties of plantain flour. Int. J. Food Sci. Technol. 2010; 45(1): 170-178.

[6] Sharrok S, Lustry C. Nutritive Value of banana, in INIBAP. Annual Report Montpellei, France. 2000; $28-31$.

[7] Guariguata L, Whiting DR, Hambleton I, Beagley J, Linnekamp U, Shaw JE. Global diabetics prevalence for 2013 and projections for 2035 Diabetics. Res. Clin. Prac. 2014; 103: 137-149.

[8] Eleazu CO, Iroaganachi M, Eleazu KC. Ameliorativve potentials of Cocoyam (Colocasia esculenta l) and unripe plantain on the relative tissue weight of streptozotocin induced diabetic rats. 2013: Article ID 160964, 8.

[9] Adegboyega OK. The proximate chemical composition, the carbohydrate and Amino Acid make up of Green and ripe plantain. African Journal of Food Agriculture Nutrition and Development. 2006: 24: (70-77).

[10] Venugopal V. Mince from low-cost fish species. Trends Food Science Technology. 1992: 3: 2-5

[11] Aneer G. In-situ observations of Baltic herring (clupea harengus membras) Spawing behaviour in the Asko-Land sort area, Northern Baltic proper. Mar. Bio. 1983; 74: 105-110.

[12] Mills LSM, Scout ME, Doak DF. The keystone species concept in ecology and conservation. Biosciences. 1993; 43: 219-224.

[13] FAO. World catch and Trade of Fisheries Productions in 1984. Info Fish Marketing Digest. $1985 ; 25$.

[14] Koffi-Nevvry R, Oulna TS, TkOSEMON M, Brou BK. Composition and lactic microfloral of Adjnevan, a traditional Ivorannn Fermented fish condition. Pakistan Journal of Nutrition. 2011; 10: 332-337.

[15] Dadzie BK, Orchad JE. Routine Post Harvest Screening of Banana/Plantain Hybrids. Criteria and methods inibap Technical Guidelines. 1997.

[16] AOAC. Official Method of Analysis. 17th ed. Association of Official Analytical Chemists, Washington, DC, USA 2005.

[17] Ihekoronye AI, Ngoddy PO. Integrated Food Science and Technology for the Tropics, Macmillan Publishers Limited, London. 1985; 236-253.

[18] Wardlaw IJ, Hamp S, Disilvestro RA. Perspective in Nutrition. Mc. Graw-Hall, New York 2004: ISBN 0-07-2442123.

[19] Kaur G, Sandhu P, Sidhu M. Microbial analysis of commonly stored food items in household refrigerators in selected containers. 2013: J. Hum Ecol. 41(2): 151-155.

[20] Uzoaga LN, Kanu NA. Microbiological Changes of Extruded Snacks Made From Orange Fleshed Sweet Potato, Cassava, Plantain, Fortified With Moringa oleifera Powder. Journal of Research in Agriculture and Animal Science. 2020; 7(1): 22-30.

[21] Collins CH, Lyne PM, Grange JM. Microbiological Methods, 6th Edition, Buttermorths, London. 1989 ; $178: 198$.

[22] Noah AA, Banjo OA. Microbial, Nutrient Composition and Sensory Qualities of Cookies fortified with Red Kidney Beans (Phaseolus vulgaris L.) and Moringa seeds (Moringa oleifera). International Journal of Microbiology and Biotechnology. 2020; 5(3): 152-158.

[23] Olorode 00, Ewuoso LM. Microbiological changes during storage of extruded snacks produced from yellow cassava substituted with processed sesame seeds flours. Frontiers in Environmental Microbiology. 2021; 7(2): 57-62.

[24] International Commission on Microbiological Specification for Foods (ICMSF). Microorganisms in Foods Microbial Ecology of Food Commodity: Springer: New York. NY, USA. 1998.

[25] Berghofer LK, Hocking AD, Miskelly D, Jansson E. Microbiology of wheat and flour milling in Australia. Intl. J. Food Microbiol. 2003; 85: 137-149.

[26] Omobolanle 00, Sunday SS. Evaluation of Qualities of extruded snacks from yellow cassava flour substituted with processed sesame seeds flours. World Journal of Advanced Research and Review. 2021: 10(1): 74-86. 